\author{
ELISABETTA GARGANI ${ }^{1}$ - SAURO SIMONI ${ }^{1}$ - CLAUDIA BENVENUTI $^{1}$ - RICCARDO FROSININI ${ }^{1}$ \\ GIAN PAOLO BARZANTI ${ }^{1}$ - PIO FEDERICO ROVERSI ${ }^{1}$ - ALESSANDRO CASELLI ${ }^{2,3}$ - MATTEO GUIDOTTI ${ }^{2}$
}

\title{
ACLEES CF. SP. FOVEATUS (COLEOPTERA CURCULIONIDAE), AN EXOTIC PEST OF FICUS CARICA IN ITALY: A SUSTAINABLE APPROACH TO DEFENCE BASED ON ALUMINOSILICATE MINERALS AS HOST PLANT MASKING SOLIDS
}

\author{
${ }^{1}$ CREA Research Centre for Plant Protection and Certification, Florence, Italy \\ ${ }^{2}$ CNR Istituto di Scienze e Tecnologie Molecolari, Milan, Italy \\ ${ }^{3}$ Department of Chemistry, University of Milan, Italy \\ Corresponding Author: elisabetta.gargani@crea.gov.it
}

\begin{abstract}
Gargani E., Simoni S., Benvenuti C., Frosinini R., Barzanti G.P., Roversi P.F., Caselli A., Guidotti M. - Aclees cf. sp. foveatus (Coleoptera Curculionidae) an exotic pest of Ficus carica in Italy: a sustainable approach to defence based on aluminosilicate minerals as host plant masking solids.
\end{abstract}

The exceptionally frequent entries of alien pest are a major source of concern for the farmers who have to protect their crops from unknown insects, often without natural enemies in the new areas. A new pest belonging to the Molytinae family (Coleoptera: Curculionidae), tribe Hylobiini, reported as Aclees sp. cf. foveatus Voss, was recently introduced in Italy. The species is responsible for severe damages in many Italian fig nurseries and orchards, particularly in the Italian Central Northern regions, i.e. Tuscany, Ligury and Latium. Currently, no active ingredients are registered against this insect on fig crops. An innovative and ecofriendly approach for controlling this exotic weevil infestation was investigated, by using montmorillonitebased clays, either in their native state or containing copper(II) species, and clinoptilolite zeolites, in order to check the perception of the adults' weevil towards the different solid materials and, subsequently, to evaluate the capability of these innovative products to act as masking agent with respect to the host plant and/or as repellent upon contact. The formulations containing copper(II)-exchanged clay and clinoptilolite zeolite showed preliminary promising results in terms of efficacy and environmental sustainability.

KEY Words: Asian fig weevil, alien pest, control, copper-containing clay, clinoptilolite zeolite, montmorillonite.

\section{INTRODUCTION}

The exponential rise in the movement of goods, food products and people are having, as a side consequence, an ever-growing number of exotic species (also referred as alien) introduced into new areas. Over the centuries, introductions of alien species have sometimes been intentional, especially in the field of organisms useful to humans, such as animals of zootechnical interest, beneficial insects, such as honey bees or different entomophagous insects, various crop plants (e.g. corn, potato, tomato, etc.) as well as ornamental species. However, often, in the case of arthropods, the entrances in new countries might have been unintentional, in particular for species, which resulted to be harmful to plants or, even, to humans. Despite complex international and national legislations aiming at hindering the diffusion of alien species from one country to another (see, for instance, EU Dir. 2000/29/CE; or Italian Law Decree 214/2005), the phenomenon is becoming increasingly topical. With regard to arthropods, it is estimated that the current rate of introduction of new insects in Italy is, at least, 6-7 new species a year (INGHILESI et al., 2013).

In 2005, a new pest belonging to the genus Aclees (Coleoptera: Curculionidae), was reported as the responsible of severe damages in fig nurseries in Tuscany (Central
Italy). To date, the infestations have been spread across many fig orchards, particularly in the Italian Central Northern regions, i.e. Tuscany, Ligury and Latium, with considerable harvest yield losses and plant deaths (GARGANI et al., 2016). The Curculionid, belonging to Molytinae family, tribe Hylobiini, is reported as Aclees sp. cf. foveatus Voss (BENELLi et al., 2014b). The species, probably of Asian origin, is strictly related to Ficus carica L. Adults, indeed, feed on the epigeal part of the plants, while larvae are xylophagous during their whole development and can cause severe damages, destroying the wood tissues of the root and the trunk. Fig plants are infested in any season, adults show two different peaks of activity in spring and in summer. However, when climatic conditions are suitable, they can feed on the plants all year round. Up to now, no fig cultivars resistant to the attacks of this pest and very few control strategies capable of containing the adult infestations of this beetle, have been reported: treatments with entomopathogenic fungi, Beauveria bassiana, gave stimulating results (GARGANI et al., 2016). Therefore, as the presence of the insect spreads from nurseries to scattered figs, if the problem will not be addressed systematically, the fig cultivation on the Italian territory might be likely decimated in a short time.

The study of eco-friendly control strategies against exotic 
insects is more and more important, not only in terms of sustainability, but also in view of the results. In fact, an efficient eradication of a newly introduced alien species, endangering plants, has never been achieved with traditional agrochemicals only. Furthermore, when a new pest is introduced in Italy, farmers have no authorized means to control the new alien species, since the current legislation requires that each agrochemical product is registered on a specific crop and also against a specific list of noxious insects.

For this reason, a round of experimental trials using a set of aluminosilicate solids to study innovative control strategies against this new pest of Italian fig was performed.

To this aim, three types of materials expected to have a detrimental effect on the ethology of Aclees cf. sp. foveatus were selected and prepared, i.e. 1) a montmorillonite-based clay from mineral origin, also known as bentonite, 2) a montmorillonite clay containing copper(II) species, obtained through cationic exchange, and 3) a clinoptilolitetype zeolite.

Clays and zeolite were here chosen as preferential materials for fig crop protection, thanks to their toxicological safety, environmental compatibility and particular physicochemical characteristics, in terms of cation-exchange capability and sorption properties. Finely ground clays are indeed able to form a homogeneous particle film on plant leaves and tissues and this proved to be a viable strategy for controlling pests and diseases (GLENN et al., 2005; CHITU et al., 2009; SILVA et al., 2013; SHARMA et al., 2016). One of the most studied clays, kaolin, is well known for its effect against insect pests, due to its contact repellency action and disruption of feeding and oviposition (BENELLI et al., 2014a). Furthermore, in more recent study, the effects of kaolinbased particle films were evaluated on the emission of host plant volatile organic compounds, finding a positive correlation between the presence of this clay on plants and a lower attraction of the host towards the insects (GERMINARA et al., 2018). In addition, since clays have a layered porous structure and can accommodate and immobilise active ingredients within the layers of their phyllosilicate structure, clays can be efficiently used as a device for the controlled release of biocides, herbicides and/or fertilisers onto host plants (CHOY et al., 2007; SinGH et al., 2009). Micronized zeolites as well are attractive candidates as crop protection products, since they create uniform films, which do not interfere with the metabolic lifecycle of the plant and, on the contrary, enhance its resistance towards high temperatures and strong solar irradiation (DE SMEDT et al., 2015). Moreover, clay- or zeolite-based formulations typically contain chemically inert minerals and the thin particle films obtained from them can be easily removed from harvested fruits by a simple washing with water. In the present case, the aluminosilicate materials were used either without any further modification in their micronized powder form or, for the montmorillonite clay only, after a treatment of cationic exchange, in order to insert copper(II) into the interlayer spaces of the solid structure. Indeed, the beneficial use of copper-containing products for controlling insect pests has been already studied for Bactrocera oleae, the key pest of olive crops (BELCARI et al., 2005). Nevertheless, since the current trend is to avoid, or at least minimize, the use of copper-containing formulations (DAGOSTIN et al., 2011; KUEHNE et al., 2017), immobilization of $\mathrm{Cu}(\mathrm{II})$ ions within the montmorillonite framework might help in reducing the overall amount of active metal and in having a controlled, smooth release of $\mathrm{Cu}$ (II) species on the host plant and eventually into the environment (Hu et al., 2006).
Then, laboratory-scale and preliminary field trials were carried out to verify their effectiveness in terms of masking the host plants and/or repellency upon contact towards the adults of $A$. cf. sp. foveatus. From ethological studies conducted so far, Aclees seems to be closely related to its host plant, F. carica. For this reason, we have studied the responses of weevil adults to plants treated with different formulations of solids covering the fig canopy.

\section{MATERIALS AND METHODS}

\section{TEST INSECTS}

The Asian fig weevils, $A$. cf. sp. foveatus, were obtained collecting adults in fig crops in Carmignano area (Prato province, Tuscany), a very well-known zone for fig production in Central Italy. The gathering step and, consequently, the laboratory trials were carried out in summer (July) and autumn (September). Before the experimental treatments, the adults were provided with fig fruits and leaves as food in entomological cages $(100 \times 60 \times 60 \mathrm{~cm})$ and were maintained under standard conditions. One pool of 10 adults, chosen randomly amongst the ones collected from the field, were used for each single trial. Twenty-four hours before the trial, the chosen adults were starved. The weevils were inserted into the experimental chamber and then their movements were monitored by an observer. Controls were carried out after $30 \mathrm{~min}, 1 \mathrm{~h}, 2 \mathrm{~h}, 3 \mathrm{~h}$ and $24 \mathrm{~h}$, counting the number of adults in the different treated cages/plants (T1 -T5).

\section{LABORATORY TESTS: EXPERIMENTAL APPARATUS}

An all-plastic five-arm device was developed at CREA DC facilities. The system consists of a central plastic chamber $(100 \mathrm{~cm} \times 25 \mathrm{~cm} \times 25 \mathrm{~cm})$ covered by a screen tissue and having a surface suitable for the insects' walking, connected with five plastic tube $(8 \mathrm{~cm}$ diameter) to five little entomological cages $(30 \mathrm{~cm} \times 20 \mathrm{~cm} \times 20 \mathrm{~cm})$, containing small fig plants $(15 \mathrm{~cm}$ high $)$ in pot $(10 \mathrm{~cm}$ diameter). During the test, a group of ten individuals were put inside the central chamber, leaving them free to move and walk towards the cages. In the five lateral cages, three fig plants treated with the solid materials to be tested, one fig treated with Naturalis ${ }^{\mathrm{TM}}$, a well-known bioinsecticide, and a fig plant treated with tap water only, as control plant, were placed. Naturalis ${ }^{\mathrm{TM}}$ contains a naturally occurring soil born fungus. This fungal pathogen of insects begins working once it comes into contact with a target pest. Additionally, against certain pests, such as some types of flies, Naturalis ${ }^{\mathrm{TM}}$ has demonstrated repellent properties, when applied in preventive treatments (CUTHBERTSON et al., 2016).

\section{CHEMICALS AND PREPARATION OF THE SOLID MATERIALS}

Bentonite Globalfeed AR, hereafter Ben, is a montmorillonite-containing natural clay of mineral origin and was kindly obtained from Laviosa Chimica Mineraria SpA (Livorno, Italy).

ROTA Mining Zeolite, hereafter Zeo, is a clinoptilolitecontaining natural clay of mineral origin and was kindly obtained from Biohelp Your Planet s.r.l. (Tarquinia, Italy).

Copper(II) nitrate hemipentahydrate (Sigma-Aldrich, $95 \%$ ) was used as received.

Each batch of Ben and Zeo to be tested in laboratory and field trials was prepared as follows. A $240 \mathrm{~g}$ batch of Ben or Zeo was washed carefully with $c a .1 \mathrm{~L}$ of deionised water (10 $\mathrm{M} \Omega \cdot \mathrm{cm}$, Elix-70, Millipore-Merck purifying apparatus), in order to remove any water-soluble species. The solid was then dispersed in $7.5 \mathrm{~L}$ of tap water just prior 
to use, by vigorous shaking and a $3.1 \mathrm{wt} . \%$ dispersion of the solid in water was hence obtained.

The physico-chemical characteristics of Ben and Zeo and their appearance are reported in Table 1 and Fig. I, respectively. The metal composition, expressed as weight percentage of metal oxides, of the pristine materials was received as technical data from the manufacturer. For $\mathrm{Si}, \mathrm{Al}$, $\mathrm{Fe}$ and $\mathrm{Ca}$, the oxide metal content was further confirmed by inductively coupled plasma optical emission spectroscopy, ICP-OES (ICAP 6300 Duo, Thermo Fisher Scientific) after mineralization of the sample with a $1: 1$ aqueous $\mathrm{HF} / \mathrm{HNO}_{3}$ mixture and quantification was obtained against genuine metal standard solutions (Fluka). The elemental analysis for total carbon and total nitrogen was performed on a PerkinElmer instrument (CHN 2400 Series II), equipped with a transistor-grade extrapure oxygen gas cylinder (SIAD, $<50$ ppmv residual $\mathrm{N}_{2}$ content) and connected to a Cahn C-30 Microbalance.

The initial Ben clay contained more than $90 \%$ of mont-

Table 1 - Physico-chemical characteristics of Ben and Zeo aluminosilicate materials.

\begin{tabular}{|c|c|c|}
\hline & Ben & Zeo \\
\hline $\mathrm{Na}_{2} \mathrm{O}^{\mathrm{a}}$ & $0.4^{\mathrm{a}}$ & $0.1^{\mathrm{a}}$ \\
\hline $\mathrm{MgO}$ & 2.3 & 1.1 \\
\hline $\mathrm{Al}_{2} \mathrm{O}_{3}$ & 14.2 & 11 \\
\hline $\mathrm{SiO}_{2}$ & 72.3 & 70.1 \\
\hline $\mathrm{P}_{2} \mathrm{O}_{5}$ & 0.03 & 0.02 \\
\hline $\mathrm{K}_{2} \mathrm{O}$ & 1.9 & 3.0 \\
\hline $\mathrm{CaO}$ & 0.9 & 3.1 \\
\hline $\mathrm{TiO}_{2}$ & 0.3 & n.d. ${ }^{\mathrm{c}}$ \\
\hline $\mathrm{MnO}$ & 0.03 & 0.1 \\
\hline $\mathrm{Fe}_{2} \mathrm{O}_{3}$ & 2.3 & 1.8 \\
\hline others minor oxides & 5.1 & 9.2 \\
\hline $\mathrm{C}^{\mathrm{b}}$ & 0.16 & 0.19 \\
\hline $\mathrm{N}^{\mathrm{b}}$ & 0.08 & 0.27 \\
\hline most abundant particle size & $25 \mu \mathrm{m}^{\mathrm{d}}$ & $20 \mu \mathrm{m}$ \\
\hline specific surface area $^{\mathrm{e}}$ & $114 \mathrm{~m}^{2} / \mathrm{g}^{\mathrm{f}}$ & $46 \mathrm{~m}^{2} / \mathrm{g}$ \\
\hline $\mathrm{CEC}^{\mathrm{g}}$ & $140 \mathrm{meq} / 100 \mathrm{~g}$ & $173 \mathrm{meq} / 100 \mathrm{~g}$ \\
\hline
\end{tabular}

a. Metal composition is expressed as metal oxide (expressed as wt.\% over the dried form of the samples); b. obtained by C,H,N elemental analysis; c. not determined; d. with $97 \%$ of the particles below $53 \mu \mathrm{m}$; e. determined by Brunauer-Emmett-Teller equation; f. specific surface area for $\mathrm{Cu}-\mathrm{Ben}=121 \mathrm{~m}^{2} / \mathrm{g}$; g. cation exchange capacity according to the ammonium acetate method.

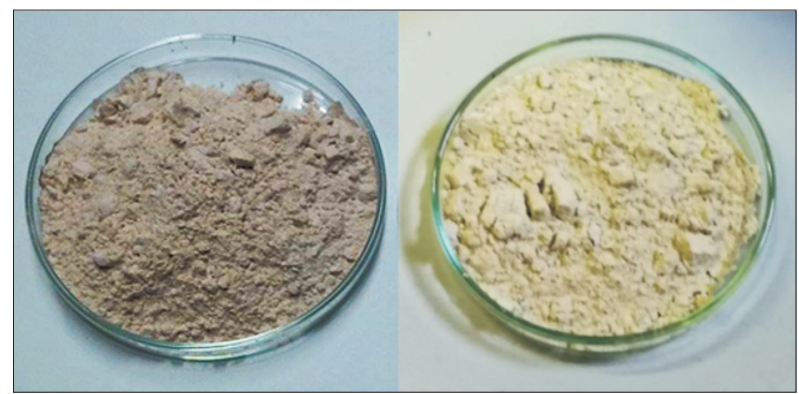

Fig. I - Appearance of the powders of Ben (left) and Zeo (right) materials. morillonite, the rest being a mixture of minor amounts of amorphous silicate and/or aluminate oxides. The initial Zeo contained at least $85 \%$ of crystalline clinoptilolite zeolite, the rest being a mixture of minor amounts of amorphous inorganic oxides. Semi-quantitative whole powder analysis (bulk mineralogy) was performed by powder X-ray Diffraction Method, XRD (Thermo ARL X'TRA-048 diffractometer with a $\mathrm{Cu} \mathrm{K} \alpha(\mathrm{k}=1.54 \AA)$ radiation).

The cation exchange capacity (CEC) of the two solids was determined by displacing the exchange sites using a 1 M solution of ammonium acetate.

$\mathrm{N}_{2}$ physisorption measurements were carried out at $77 \mathrm{~K}$ in the relative pressure range from $1 \times 10^{-6}$ to $1 \mathrm{P} / \mathrm{P}_{0}$ (Quantachrome Autosorb1MP/TCD instrument). The specific surface area values were determined by using BrunauerEmmett-Teller equation, in the relative pressure range from 0.01 to $0.1 \mathrm{P} / \mathrm{P}_{0}$.

The copper-containing batch, $\mathrm{Cu}-\mathrm{Ben}$, on the contrary, was prepared from the pristine Ben material by cationic exchange with aqueous solution of copper(II) salt precursor. In detail, $72.5 \mathrm{~g}$ of $\mathrm{Cu}\left(\mathrm{NO}_{3}\right)_{2} \cdot 2.5 \mathrm{H}_{2} \mathrm{O}$ were dissolved in $250 \mathrm{~mL}$ of deionised water. Then, $240 \mathrm{~g}$ of Ben was slowly added to the solution in small aliquots, under mechanical stirring at $250 \mathrm{rpm}$. After the addition, the total volume of the suspension was brought to $1 \mathrm{~L}$ by a further addition of deionised water and homogeneously stirred for $4 \mathrm{~h}$. The suspension was then decanted and thoroughly rinsed with $1 \mathrm{~L}$ of fresh deionised water, in order to remove $\mathrm{Cu}$ (II) species in excess from the liquid phase. The rinsing step was repeated 8 times, so to obtain an almost colourless upper layer above the decanted solid. The concentrated suspension was finally diluted to $7.5 \mathrm{~L}$, by addition of tap water just prior to use, by vigorous shaking and an overall $3.1 \mathrm{wt} . \%$ dispersion of the solid in water was hence obtained.

A small fraction of the $\mathrm{Cu}$-Ben was withdrawn and dried. The content of $\mathrm{Cu}(\mathrm{II})$ in the solid was $3.43 \mathrm{wt} . \%$, as obtained by indirect iodometric titration of $\mathrm{Cu}$ (II) species in the residual aqueous phase. The content of $\mathrm{C}$ and $\mathrm{N}$, as from elemental analysis (see above), was 0.17 wt.\% and 0.18 wt. $\%$, respectively.

Naturalis ${ }^{\mathrm{TM}}$, the fourth treatment/thesis (Nat), is a commercial registered bio insecticide, based on living spores of naturally occurring strains of the entomopathogenic fungus Beauveria bassiana (Bals.-Criv.) Vuillemin (Strain ATCC74040, $7.16 \mathrm{~g}$, equal to $2.3 \times 10^{7}$ viable spores $/ \mathrm{mL}$ ): the product was use at label dose (Table 2).

\section{FIELD TEST}

At the end of July, the experimental solids (Table 2) were tested in preliminary field trials. In the fig production area of Carmignano (Prato province, Tuscany), three young fig plants/thesis were treated with the $3.1 \mathrm{wt} . \%$ aqueous suspensions, as described above. The solid-in-water fine suspension of the products was spread onto the crop trees by means of a backpack sprayer at normal volume. Controls, performed with visual observation on the damage on the fig plants, were carried out at the end of September. The visual inspection was carried out on the whole plant, counting the damaged and healthy shoots.

\section{STATISTICAL ANALYSIS}

The effect of collection period of the insects to be tested, of the check time and of the treatment were analysed by GLM (General Linear Model) and significance evaluated by Duncan test $(\mathrm{P}<0.05)$. 
Table 2 - Products tested in 2017 in laboratory and in field trials.

\begin{tabular}{ll}
\hline \hline & Treatment \\
\hline T1 - Ben & \\
Globalfeed-AR clay & \\
Suspension 3.1 wt.\%
\end{tabular}

\section{T 2 - Cu-Ben}

Globalfeed-AR - $\mathrm{Cu}(\mathrm{II})$-exchanged montmorillonite clay

Suspension 3.1 wt. $\%$

\section{T 3 - Zeo}

Zeolite, natural clinoptilolite, Rota mining

Suspension $3.1 \mathrm{wt} . \%$

\section{T4 - Nat}

Naturalis ${ }^{\mathrm{TM}}$, Beauveria bassiana $7.16 \mathrm{~g}\left(>2.3 \times 10^{7}\right.$ spores $\left./ \mathrm{mL}\right)$ Coformulants up to $100 \mathrm{~g}$

\section{T 5 - Check}

(tap water treatment)

\section{RESULTS AND DISCUSSION}

It is worth highlighting that the insects' choice is more stable after 24 hours from the start of the test: at this check time, we registered a consolidate selection for the plant/ cage. During the laboratory trials, we observed that the insects' movement was affected by the treatment/thesis: they, in fact, differently colonized the five cages $\left(\mathrm{F}_{1.5}=3.01\right.$; $\mathrm{P}=0.02$ ). As shown in the graph, the formulations that the fig weevils chose less, were the $\mathrm{Cu}-\mathrm{Ben}$ and Zeo samples (Fig. II). It is thus a first indication that these two solids could be active as masking substances on the host plants, likely confusing the insects in the search for them. The presence of a coating film of zeolite or metal-exchanged clay indeed proved to be able to modify the physicochemical characteristics of the crop surface (in particular, the $\mathrm{pH}$ and the emission of volatile organics from fruits and leaves) and this may disorient the insect (LARENTZAKI et al., 2008; De Smedt et al., 2015; Sharma et al., 2015). The insects, during their choosing activity, went directly to the fig plant and made a first contact with the leaves, drumming with antennas the surface. For the not selected thesis there was no contact with the plant. The slow release of $\mathrm{Cu}(\mathrm{II})$ soluble species, via leaching out of the clay structure, can additionally have a detrimental effect on the surface microorganisms present on the target plant (WALTERS, 2006), thus causing a supplementary disorienting factor for the weevil.

The two different pools of insects, collected during summer or autumn, gave different results in terms of performance of their movements. The adults collected in summer were more mobile and made their choice amongst the cages more quickly (Fig. III). On the other hand, the adults collected in September showed the typical traits in approaching winter period.

With regard to the preliminary field trials, from a visual control on the whole plant and counting on the healthy and damaged fig sprouts, it was confirmed that the formulations containing the $\mathrm{Cu}$ (II)-modified montmorillonite clay, $\mathrm{Cu}-$ Ben, and the natural clinoptilolite zeolite, Zeo, showed good results, as they were less preferred. In fact, while the plants treated with the unmodified clay, Ben, and the check figs presented a high number of shoots with erosions (15 damaged sprouts out of 20 inspected for the Check, and 7 damaged out of 25 inspected for Ben), the plants of the two thesis treated with $\mathrm{Cu}-\mathrm{Ben}$ and Zeo were healthy (no damaged sprouts).

As far as the preparation of the formulation is concerned,

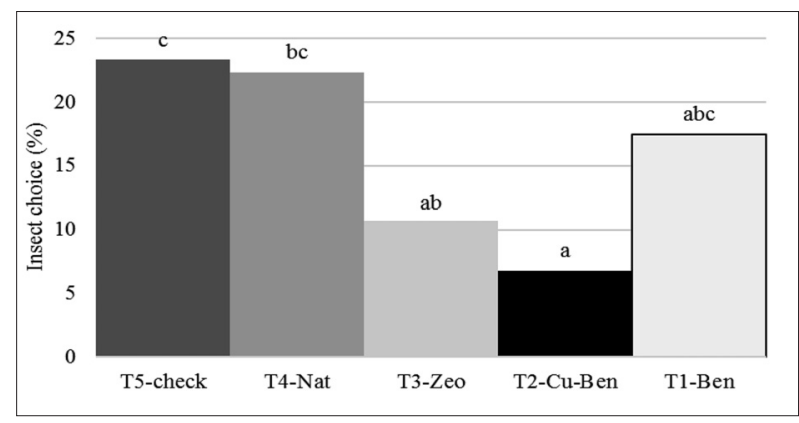

Fig. II - Insect choices registered at different intervals (Duncan test, $\mathrm{P}>0.05$ ). Different letters indicate significative differences.

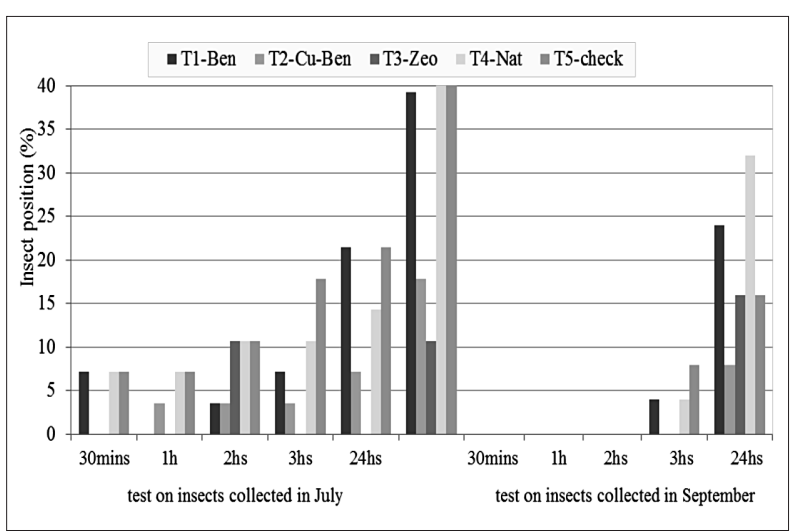

Fig. III - Different times of choice in summer and autumn Aclees adults.

since the Zeo sample was used in its natural form, after a simple rinsing and suspension in water, without any further time-consuming ion-exchange procedures, it proved to be a viable and economically sustainable alternative approach for controlling the fig weevil. Moreover, the absence of added copper species in the Zeo formulation makes it more promising and environmentally sustainable than other currently available commercial products containing copper salts as active ingredients, whose use is being gradually reduced or, better, phased out, especially in organic and/or sustainable farming (CABÚs et al., 2017; KUEHNE et al., 2017).

\section{CONCLUSIONS}

Although the exotic weevil Aclees cf. sp. foveatus is not included in the list of quarantine species, the problems resulting from its infestations on the Italian production of the fig tree could be relevant. To date, its infestations are present in Tuscany, Latium and Ligury, but its population might reach Southern regions, where fig crops are an important economical resource. No products for the control of the insect populations have been registered so far. Furthermore, the ethology of the weevil, which spends the entire period of its preimaginal development inside the fig tree tissues, makes it very difficult to think of a possible use of the most common synthetic agrochemicals. Now, the new strategic approach presented in this study, testing innovative formulations that could have an impact on the selection of the target plant by the insect, by masking the chemical signals of the fig tree to the weevil, could be a successful strategy to solve the problem. 
In this case, a $\mathrm{Cu}(\mathrm{II})$-containing montmorillonite clay, $\mathrm{Cu}-\mathrm{Ben}$, and a clinoptilolite zeolite from mineral origin, Zeo, displayed the most promising results, both in laboratory-scale tests and in open-field trials. The application of the aqueous formulations containing one of these two solids onto the fig plants resulted in no evident attacks by $A$. cf. sp. foveatus. Furthermore, Zeo-based formulation was obtained via a simple and cheap preparation sequence, without any addition of copper(II) salt precursors. For these reasons, clinoptilolite zeolite Zeo, together with copperexchanged clay, $\mathrm{Cu}-\mathrm{Ben}$, may be considered economically and environmentally sustainable innovative methods for controlling Aclees cf. sp. foveatus, as an alternative to other commercial insecticide products. Their efficacy can be attributed to a masking effect of the volatile organic compounds released by the host plant substances, thus affecting the insect's choice.

Even in the case of alien pests, an integrated and multidisciplinary approach to defence turns out to be the winning strategy and so, also the use of inorganic oxide zeoliteor phyllosilicates-based products could deserve further investigation, as an initial control strategy against alien insect species.

\section{ACKNOWLEDGMENTS}

Thanks to Mr. Siro Petracchi, Associazione produttori fichi secchi di Carmignano, (PO), Dr. R. Ercolani, Biohelp Your Planet s.r.l. (Tarquinia, Italy) and Dr. E. Menicagli, Laviosa Chimica Mineraria SpA (Livorno, Italy) for providing samples of the inorganic supports. Mr. Francesco Cazzulani is kindly acknowledged for the preparation of large batches of clay and mineral samples.

\section{REFERENCES}

Belcari A., Sacchetti P., Rosi M.C., Del Pianta R., 2005 - Control of the olive fly (Bactrocera oleae) through the use of copper products in Central Italy. - IOBC/WPRS Bull., 28: 45-48.

Benelli G., Caruso G., Canale A., Gucci R., 2014a - Il controllo eco-compatibile della mosca delle olive. Frutticoltura, 4: 42-44.

Benelli G., Meregalli M., Canale A., 2014b - Field observations on the mating behavior of Aclees sp. cf. foveatus Voss (Coleoptera: Curculionidae), an exotic pest noxious to fig orchards. - Journal of Insect Behavior, 27: 419-427.

Cabús A., Pellini M., Zanzotti R., Devigili L., Maines R., Giovannini O., Mattedi L., Mescalchin E., 2017 Efficacy of reduced copper dosages against Plasmopara viticola in organic agriculture. - Crop Protection, 96: 103-108.

Chitu V., Chitu E., Marin F.C., Ionita A.D., Filipescu L., PIRLEA M., 2009 - Studies of Foliar Applied Clay Effects on the Apple Fruit Quality. - Acta Horticulturae, 884(2): 441-447.

Choy J.H., Choi S.J., Oh J.M., Park T., 2007 - Clay minerals and layered double hydroxides for novel biological applications. - Applied Clay Science, 36 (1-3): 122-132.

Cuthbertson A.G.S., Audsley N., 2016 - Further Screening of Entomopathogenic Fungi and Nematodes as Control Agents for Drosophila suzukii. - Insects, 7: 1-10.

Dagostin S., SchäRer H.J., Pertot I., TAMm L., 2011 - Are there alternatives to copper for controlling grapevine downy mildew in organic viticulture? - Crop Protection, 30(7): 776-788.

De Smedt C., Someus E., Spanoghe P., 2015 - Potential and actual uses of zeolites in crop protection. - Pest Management Science, 71: 1355-1367.

Gargani E., Mazza G., Benvenuti C., Torrini G., Strangi A., Pennacchio F., Roversi P.F., 2016 Biological control of Aclees $s p$. $c f$. foveatus and first recovery of an associate Beauveria bassiana strain. Redia, 99: 29-33. http://dx.doi.org/10.19263/REDIA99.16.05

Germinara G.S., Rotundo G., Pistillo M., De CrisTOFARO A., 2018 - Kaolin-based particle film interferes with granary weevil orientation towards wheat kernels. Book of Abstract XI European Congress of Entomology, Napoli 2-5 July 2018: 136.

GlenN D.M., Puterka G.J., 2005 - Particle Films: A New Technology for Agriculture - Horticultural Reviews: Vol. 31, Janick J, (Ed.), J. Wiley \& Sons, Inc.: 1-44.

Hu C.H., XIA M.S., 2006 - Adsorption and antibacterial effect of copper-exchanged montmorillonite on Escherichia coli $K_{88}$ - Applied Clay Science, 31(3-4): 180-184.

Inghilesi A.F., Mazza G., Cervo R., GHerardi F., SPosimo P., Tricarico E., Zapparoli M., 2013 - Alien insects in Italy: Comparing patterns from the regional to European level. - Journal of Insect Science, 13: art. 73.

Kuehne S., Rossberg D., Roehrig P., von Mering F., Weihrauch F., Kanthak S., Kienzle J., Patzwahl W., Reiners E., Gitzel J., 2017 - The Use of Copper Pesticides in Germany and the Search for Minimization and Replacement Strategies. - Organic Farming, 3(1): 6675.

Larentzaki E., Shelton A.M., Plate J., 2008 - Effect of kaolin particle film on Thrips tabaci (Thysanoptera: Thripidae), oviposition, feeding and development on onions: A lab and field case study. - Crop Protection, 27: 727-734.

ShaRma R.R., ViJAY RAKESH RedDy S., DATTA S.C., 2016 Particle films and their applications in horticultural crops. - Applied Clay Science, 116-117: 54-68.

Silva C.A.D., Ramalho F.S., 2013 - Kaolin spraying protects cotton plants against damages by boll weevil Anthonomus grandis Boheman (Coleoptera: Curculionidae). - J. Pest Sci., 86: 563-569.

Singh B., Sharma D.K., Kumar R., Gupta A., 2009 Controlled release of the fungicide thiram from starchalginate-clay based formulation. - Applied Clay Science, 45(1-2): 76-82.

WALTERS D.R., 2006 - Disguising the leaf surface: the use of leaf coatings for plant disease control. - European Journal of Plant Pathology, 114: 255-260. 
206 - Blank Page 